\title{
RETHINKING LINKAGE TO THE WEST: WHAT AUTHORITARIAN STABILITY IN SINGAPORE TELLS US
}

\author{
Su-Mei Ooi ${ }^{*}$ \\ Department of Political Science, \\ Butler University, 4600 Sunset Ave, Jordan Hall, \\ Indianapolis IN 46208, United States \\ email: sooi@butler.edu
}

Published online: 15 July 2016

To cite this article: Su-Mei, O. 2016. Rethinking linkage to the West: What authoritarian stability in Singapore tells us. International Journal of Asia Pacific Studies 12 (2): 1-29, DOI: $10.21315 /$ ijaps2016.12.2.1

To link to this article: http://dx.doi.org/10.21315/ijaps2016.12.2.1

\begin{abstract}
Recent regime change literatures compellingly assert that linkage to the West has been a significant factor in democratisation where the organisational capacity of authoritarian incumbents has overwhelmingly weakened pro-democracy forces. Detailed case studies confirming these findings have not included Singapore although high levels of linkage to the West suggest that democratisation should have taken place there. This qualitative case study fills the empirical and theoretical gap by explaining why linkage has so far failed to raise the cost of authoritarianism for Singapore's government. By eschewing the current structural approach, which conceptualises linkage as mere channels of external pressure or influence, this analysis treats each dimension of linkage as arenas of political interaction where external democratising pressure or influence are generated, mediated or precluded. This agency-centred approach exposes the politics of linkage and thereby enables us to explain why linkage to the West does not always have the expected impact on regime change. These findings open up the research agenda of regime change studies by pointing the way forward for future studies of otherwise inexplicable cases where high linkage has not led to democratisation.
\end{abstract}

Keywords: Democratisation, authoritarianism, Singapore, linkage, Southeast Asia, authoritarian stability 


\section{INTRODUCTION}

The notion that democratisation is for the most part a domestic political process exploded when the end of the former Soviet Union corresponded with a dramatic sweep of transitions away from communism toward the promise of democracy (Whitehead 2001). Early efforts to understand how the international environment impacts regime change have since continued, re-animated by the fact that a significant number of post-Cold War, "third wave" regime transitions have led instead to authoritarian transformations. This trend is theoretically significant in that myriad scholarship suggested that the overarching post-Cold War geopolitical environment was significantly more conducive to democratisation, regional factors notwithstanding (Whitehead 2001; Pridham et al. 1994). Exactly how the international-domestic political interface shapes divergent regime outcomes has remained a question of salience. Arguably, one of the most significant contributions in this regard consists of efforts to develop a theory that allows us to understand what international factors matter and how they matter to regime change. A series of recent scholarship by Levitsky and Way $(2005 ; 2006 ; 2007 ; 2010)$, which culminated in a cross-regional, medium-N case study in 2010, has made such an impact in the field by giving us a framework to approach the complexities of the international environment and its impact on regime change.

The purpose of this article is to re-examine a set of international factors that the authors term collectively as "linkage to the West," in order to understand why, contrary to their theory, they did not have a democratisation effect on Singapore. To understand why this enterprise is of any significance will require further elaboration of Levitsky and Way's theory and where Singapore fits in their study. Levitsky and Way's theory begins by positing that high levels of organisational power, derived from state coercive capacity, party strength and state economic control, are key domestic factors that inhibit democratisation (2010: 54-70). Authoritarian incumbents who enjoy high levels of elite cohesion and coercive state capacities can easily thwart oppositional challenges, explaining why many promising transitions have culminated in hybrid "electoral authoritarian" regimes and changed no further (Levitsky and Way 2010: 54-68). However, their medium-N case studies showed that sustained external democratising influence provided by linkage to the West contributed significantly to democratisation. Defined as ties to or cross-border flows with the West, linkage consists of at least six key dimensions-economic, intergovernmental, technocratic, informational, social and transnational civil society. Economic linkage consists of trade, investment and credit flows. 
Intergovernmental linkage consists of bilateral diplomatic and military ties and participation in Western-led alliances, treaties and international organisations whilst technocratic linkages refer to the share of a country's elite educated in or with professional ties to Western-led multilateral institutions or universities. Informational linkages refer to cross-border telecommunications, internet connections, and Western-media penetration. Last but not least, social linkages comprise tourism, immigration and refugee flows and diaspora networks, whilst transnational civil society linkages are tied to international non-governmental organisations (NGOs), churches, party organisations, and other networks (Levitsky and Way 2010: 43).

Through process-tracing, their research shows that these forms of linkage to the West tilt the balance of power against authoritarian incumbents by heightening the salience in the West of authoritarian government abuse, increasing the probability of an international response, creating domestic constituencies with a stake in adhering to democratic norms and ultimately strengthening democratic forces in relation to autocrats. It is through these mechanisms that linkage raises the cost of authoritarianism, making it imperative for authoritarian incumbents to democratise as per oppositional demands. The more extensive linkages are maintained to the West, the more likely obstacles of high organisational capacity can be overcome. The authors also identify another means through which external democratising pressure and influence can be channelled. Leverage, defined as the "authoritarian governments' vulnerability to external democratising pressure" from the West, is exercised through a variety of ways including "political conditionality and punitive sanctions, diplomatic pressure, and military intervention." Leverage also raises the cost of authoritarianism, but as it tends to provide merely superficial external pressure or influence over a limited period of time, its significance is limited to cases where the organisational power of incumbents is already low (Levitsky and Way 2010: 43).

Levitsky and Way's cases were chosen on the basis of being hybrid "competitive authoritarian" regimes, where elections are not free and fair, but allow a minimal degree of political competition such that an electoral upset is a possibility (2010: 5). Although they do not claim to offer a general theory that applies to all regime types, they do extend their discussion to very similar "hegemonic authoritarian" regimes, where even a minimal degree of political competition does not exist despite regular elections (Levitsky and Way 2010: 34; Howard and Roessler 2006: 367). In fact, the robustness of their theory is enhanced by the fact that even less competitive 
regimes appear mostly to comply with the general predictions of their theory (Levitsky and Way 2010: 343). The only exception was that of Singapore, a hegemonic authoritarian regime "which remained authoritarian despite relatively high linkage" (Levitsky and Way 2010: 343). Because Singapore was not in the original pool of case studies, no clear explanation was ever provided for why it defies predictions. Yet, as Rodan and Jayasuriya point out, the case is "starkly at odds with their theory" (Rodan and Jayasuriya 2012: 181). Since linkage to the West still impacts hegemonic authoritarian regimes in the manner predicted by Levitsky and Way's theory, why extensive linkage to the West does not work to channel external democratising pressure and influence to effect regime change there seems to demand some further explanation. Indeed, why Singapore remained immune to the zeitgeist of democracy during a period of Western liberal hegemony, despite high levels of linkage to the West, is both an empirical and theoretical puzzle that needs to be addressed. This is not only because students of Singapore's politics would appreciate a clarification as to why the case does not "fit" the theory - the case may indeed suggest that theoretical refinements may be necessary for a better understanding of the international-domestic interface of regime change.

The analysis provided in this article will centre on Singapore's linkages to the West in order to explain why these linkages did not raise the cost of authoritarianism for the People's Action Party (PAP) government. The first part of this analysis centres on examining the reasons for which intergovernmental, economic and technocratic linkages had no effect on raising the cost of authoritarianism, whilst informational linkages had only a weak impact. I part ways with Levitsky and Way by extending the analysis of these linkages into the Cold War period. Levitsky and Way do not do so because they "do not expect linkages to have had similar effects during the Cold War period" and their theory is "relevant only for periods of Western liberal hegemony" (2010: 34). As I will show, such an approach obscures important continuities in the way linkages behaved during both periods. More importantly, including the Cold War period in the analysis highlights the reasons for those continuities, rooted in the consistency of autocratic agency and enduring Western interests, Western liberal hegemony notwithstanding.

The second part of the analysis follows logically from the first by suggesting that the remaining social and transnational civil society linkages had the most potential to raise the cost of authoritarianism in Singapore. Indeed, other studies have shown that such linkages are not insignificant political arenas in which bottom-up pressures for democratisation can be generated to compensate for weak external state pressure, or help to 
generate external state pressure (Ooi 2009 and 2013). These are empirically rich case studies that detail social and transnational civil society linkages as interactive arenas in which external democratising pressures are generated. Consistent with such an approach, which best foregrounds autocratic agency, I trace the ways in which the PAP government has consistently depoliticised such social and civil society linkages to minimise the generation of such pressures. The analysis focuses in particular on a critical moment in Singapore's political history when political opening could have been possible (late 1980s and early 1990s), and explains how decisive actions taken by the incumbents to crackdown on politicised elements that comprised these social and civil society linkages to the West had a lasting depoliticising effect on these linkages. ${ }^{1}$ This ultimately weakened democratic forces and discouraged the development of domestic constituencies with a stake in adhering to democratic norms well into the post-Cold War period. Wide-ranging social and transnational civil society linkages to the West have therefore not raised the cost of authoritarianism significantly.

What emerges from this historical case study is that a conceptual flaw in the current theory obscures the politics of linkage and thus inhibits a satisfactory explanation for why linkages to the West have failed to raise the cost of authoritarianism in a high linkage case like Singapore. By treating them as mere channels of external democratising pressure and influence, the literature fails to treat linkages as arenas of political interaction where external democratising pressure and influence can either be generated, minimised or precluded. This overly structural conceptualisation thus associates high levels of linkage with high levels of external pressure and influence, which this case study suggests is rather contingent upon agency. The agency-centred approach used here betters our understanding of the international-domestic political interface within which regime change is located. In order to situate this analysis in current conversations on regime change, we will review how authoritarian stability in Singapore has thus far been explained.

\section{EXPLAINING AUTHORITATION STABILITY IN SINGAPORE}

Singapore has long been a puzzle because it debunks key explanations of democratisation - it reached a level of development by the late 1970s that Huntington would have called the "political transition zone" without experiencing democratic breakthrough (Huntington 1991: 60). The attendant 
social structural changes predicted by modernisationists - namely, the rise of a liberal middle class - did not lead to substantial pressure for democratisation (Lipset 1959). While Singapore is empirically and theoretically exceptional on many counts, it can be understood through the existing theoretical literature on regime change and many studies have "fit" it into existing theoretical frameworks so that it is possible to think of Singapore meaningfully. For example, the failure of modernisation theory to predict authoritarian persistence in Singapore may be understood by examining the role of capitalist and working classes and the importance of class coalitions (Moore 1966; Rueschemeyer et al. 1992; Collier 1999). Trocki (2006) describes how the PAP politically neutered both the local capitalist and working classes early on, preventing such strong class coalitions from forming, confirming Khong's (1995) earlier observation of the political impotence of Singapore's local capitalists in acquiescing to authoritarian control for the protection the state could provide against labour agitation, and Pereira's (2008) subsequent explanation for its continued weakness. More recent class tensions between the middle and lower classes have further weakened democratic forces that do exist in Singapore by precluding the possibility of large cross sections of opposition (Tan 2004).

Dimensions of what Levitsky and Way call high organisational capacity have also been well-developed explanations for authoritarian stability in Singapore. The developmental state literature, for example, has suggested that late industrialisation often necessitates a "hard state" which exercises societal control with significant authoritarian overtones (Johnson 1982; Woo-Cumings 1999). In the case of Singapore, the hard developmental state had already been shaped by the "counterrevolutionary collaboration between British and local elites under late-colonial rule during the 1940s and 1950s" (Slater 2012). Its development during the Cold War and when the Indonesian threat to national security seemed imminent had the effect of further hardening it. Such state-society relations continue to exist in Singapore even in the post-industrial age (Rodan 1989; Huff 1994). Indeed, Slater (2012) attributes authoritarian durability in Singapore to the continued existence of the strong state. The coercive aspects of state capacity are further maintained by archaic laws such as the Internal Security Act (ISA), and a legal system effectively controlled by the executive and therefore rules consistently against opposition politicians and activists in "defamation" cases.

Party strength has also contributed to authoritarian stability in Singapore - it is a case consistent with the statistical findings of Geddes that single party regimes last longer than personalist and military ones (1999: 122). The high level of elite cohesion in Singapore certainly confirms the 
regime stabilising effect of parties and the resultant claim that single-party regimes tend to be brought down by exogenous events and not internal splits (Huntington 1991; Haggard and Kaufman 1995; Smith 2005; Brownlee 2007). Further, Slater (2012) has shown that the cohesion of a broad spectrum of political, economic and social elites is very much forged by recognised threats to their shared interests from class and communal sources. Mass mobilisation and conflict along class and communal lines between 1945 and 1965 is said to have led to the "ordering" of elites even before Indonesia's Konfrontasi campaign of 1963-1965 made geopolitical vulnerability a significant source of Singapore's "insecurity complex." (Rahim 2009). To this conversation on elite cohesion, Levitsky and Way (2012) have added an ideational dimension, forged often through the shared experience of violence. In Singapore's post World War II history, counterinsurgency efforts, communal violence and later, security threats from without (Konfrontasi) helped to consolidate a generation of leadership with what Levitsky and Way call "extraordinary legitimacy and unquestioned authority," despite the lack of nationalist heroism-helping to explain the relative lack of factional conflict within the PAP (Levitsky and Way 2012: 871). On top of its monopolistic control over the (coercive) state apparatus, it is this elite cohesion that has been an important source of the PAP's ability to maintain "party strength." With the aid of the first-past-the-post electoral system, this has led to the PAP's predominance in Parliament, which has further allowed the PAP to develop legalistic means of punishment for those who do not comply.

The above literatures suggest that coercive state capacity and party strength have been mutually reinforcing, creating tremendous obstacles for democratisation. The literatures on the evolution of Singapore's "developmental state" also help to explain the extensive control the partystate has on the economy, however, not least through government-linked or government-linked corporations (GLCs), which have directly competed with local private interests after 1965 along with foreign-owned companies, and numerous statutory boards (Trocki 2006; Rodan and Hewison 2001). The numerous GLCs are a key source of employment for Singaporeans. Further, the party-government's control over private savings and capital has been exercised through GLCs such as the Development Bank of Singapore, which remains only partially privatised today (Rodan 2004). Importantly, economic control is also extended through that of the Central Provident Fund (CPF) - the government-controlled compulsory savings programwhich is also a large source of financing for the majority of the population's purchase of the Housing Development Board's expansive public housing. 
Key means of production and finance are therefore under the PAP government's control, and this control furnishes its ability to extend political control through myriad organisations from the media to grassroots committees. On all three fronts - coercive state capacity, party strength and economic control - the incumbent PAP regime thus maintains a high level of organisational capacity.

This literature survey suggests that authoritarian stability in Singapore should not, in fact, come as a surprise. Why extensive linkages to the West have not raised the cost of authoritarianism for the PAP government despite its high organisational capacity is still something that needs to be explained, however. In this regard, Rodan and Jayasuriya suggest that Levitsky and Way's inability to do so lies in the failure to understand how "capitalist development fundamentally influences the nature of societal forces and the conflicts between them" and forges "consensus politics" (2012: 181). This is not a significant departure from the literatures cited earlier, which highlight the political neutering of capitalist and working classes in Singapore. Importantly, a "social foundations approach" like theirs does better capture how the fusion of state and party created a new class of politico-bureaucrats "predisposed toward more bureaucratic and administrative techniques of political control and mobilisation, but also a form of state capitalism that rendered many Singaporeans directly or indirectly dependent on the state for economic and social resources," thus fostering "vulnerability to political cooptation and intimidation" (Rodan and Jayasuriya 2012: 186). Indeed, systemic exposure to "an institutionalised ideology that champions the role of technocratic elites at the expense of ideas of representation and citizenship rights" helps to explain why democratic forces in Singapore lack a strong social base to mount their opposition to authoritarian rule (Rodan and Jayasuriya 2012: 186). Altogether, these socio-structural factors help us to understand that we cannot simply assume that authoritarian regimes like Singapore would ever democratise.

It is important to note that the focus of their explanation of authoritarian stability in Singapore is on the inherent character of the regime, forged through a particular path of capitalist development it took. Their analysis of the socio-structural factors of "consensus politics" in Singapore does not include an explanation of exactly how these domestic factors mediate the democratising impact of linkages to the West, however. Although their analysis is directed at Levitsky and Way's failure to explain the case of Singapore, there remains a sense that their approach still sidesteps the issue by reasserting the primacy of domestic factors in accounting for authoritarian stability. How these factors impact the politics of linkage and contribute to the failure to raise the cost of authoritarianism is 
still obscure. It is for this reason that this analysis focuses explicitly on the linkages themselves.

\section{INTERGOVERNMENTAL, ECONOMIC, TECHNOCRATIC AND INFORMATIONAL LINKAGES TO THE WEST}

In Levitsky and Way's work linkage to the West is conceptualised as "transmitters of international influence," or neutral channels through which external democratising influences flow (2010: 44). Instead of treating the six dimensions of linkage collectively as mere channels for external democratising pressures and influence, I analyse each dimension of linkage in order to highlight the politics that underpin each form of linkage. By doing so I develop my argument that the structural nature of the original conceptualisation is a failure to understand linkages to the West as sources of political pressure and influence, dislocating from analysis arenas of interaction where such pressures are generated, mediated or precluded. Table 1, which specifies the content of linkages as they apply to Singapore, also summarises the impact that various dimensions of linkage to the West have had on raising the cost of authoritarianism.

The extent of intergovernmental linkages Singapore maintains with the West is well documented in myriad literatures and will not be elaborated on here (Gillis 2005). Singapore is an active participant in 49 regional and Western-led international organisations to date and despite its declaration of nonalignment in the 1960s, was supportive of Western-led alliances during the Cold War (Leifer 1986). In all areas, perhaps with the exception of human rights, Singapore has played by international rules of the game. The PAP government quickly established itself as the West's best bet against communism on the island to the UK and US. Precisely because of the leadership's positioning of Singapore in its geopolitical relationship to the West, the latter has historically never had any vested interest in undermining a stable, pro-West government whose existence in a Malay Muslim region already seemed at times precarious. Despite the refusal to be openly identified as a US ally and occasionally criticising US policy in the region, Singapore was a consistent advocate for US military presence in the region during the Cold War, faithfully servicing US warships and providing training for Vietnamese officers during the Vietnam War (Guan 2009). Today, such a symbiotic intergovernmental relationship that serves the American national interest continues to exist as the US rebalances to the Asia Pacific - four littoral combat ships will be deployed there by 2018 as 
tensions with China in the South China Sea builds (The Diplomat 19 February 2015). It is also for these reasons that there has historically been no perceptible effort to either generate pressure on the PAP government or influence the politics of Singapore through such intergovernmental linkages.

Table 1: Linkage to the West and its effect on raising the cost of authoritarianism.

\begin{tabular}{lc}
\hline Dimensions of Linkage & $\begin{array}{c}\text { Effect on Raising Cost of } \\
\text { Authoritarianism }\end{array}$ \\
\hline $\begin{array}{l}\text { Intergovernmental Linkage } \\
\text { (Bilateral diplomatic and military ties; participation } \\
\text { in Western-led alliances, treaties and international } \\
\text { organisations) }\end{array}$ & None \\
$\begin{array}{l}\text { Economic Linkage } \\
\text { (Trade, investment and credit flows) }\end{array}$ & None \\
$\begin{array}{l}\text { Technocratic Linkage } \\
\text { (Western educated elites with professional ties to } \\
\text { Western-led multilateral institutions or universities) }\end{array}$ & None \\
$\begin{array}{l}\text { Informational Linkage } \\
\text { (Western media penetration, internet) }\end{array}$ & Weak \\
$\begin{array}{l}\text { Social Linkage } \\
\text { (Student and diaspora networks) }\end{array}$ & Weak \\
$\begin{array}{l}\text { Transnational Civil Society Linkage } \\
\text { (International human rights NGOs, international } \\
\text { legal professional organisations, churches) }\end{array}$ & Weak \\
\hline
\end{tabular}

Similarly, economic linkages have failed to raise the cost of authoritarianism in Singapore because it did not serve Western interests to generate significant democratising pressure on the PAP government. The cornerstone of the PAP's development strategy had been to provide generous tax breaks, first class legal, financial and physical infrastructure, an efficient bureaucracy and a highly skilled, English-speaking workforce to attract foreign direct investment. The PAP's brand of capitalism and its control over society yielded a stable investment environment that worked for Western economic and political interests. ${ }^{2}$ The adroitness of Singapore's economy is often attributed in the West to the capabilities of the PAP leadership - supported by the social docility cultivated under strongman rule. In the post-Cold War, post-industrial period, the PAP has preserved the continuity of such foreign economic interests by reorienting toward a "knowledge economy" (Finegold et al. 2004).

Further, Singapore's "economic miracle" was useful to the West in the ideological dimensions of the Cold War. In the Cold War and early postCold War context, Singapore stood as a shining example of how economic 
linkages to the West and free market capitalism can emancipate nations from underdevelopment or stagnation. Singapore's economic tsar Dr. Goh Keng Swee positioned the country as a potential model for emulation to the developing world when he stated, "If our experience can be used as a general guide to policy in other developing countries, the lesson is that the free enterprise system, correctly nurtured and adroitly handled, can serve as a powerful and versatile instrument of economic growth" (Goh 1999). Although Singapore's leadership often challenged notions of democracy and human rights norms associated with the West, such suggestions on the economic front lent itself to the ideological ascendency of the West during both the Cold War and post-Cold War periods, and further underlined the benefits of economic linkage to the West. Singapore also served the wider Western agenda of reorienting China when Dr. Goh served as the economic advisor to the State Council of China on coastal development between 1985 and 1995 (Gill et al. 2006). This has meant that the West is incentivised to refrain from exerting pressure on the PAP government to any significant extent. Singapore's apparent modernity and the lack of repression at a notable scale from the late 1970s onward has made it possible for Western governments to largely ignore the authoritarian nature of the PAP's rule, of which they have been well aware. ${ }^{3}$

As intergovernmental and economic linkages to the West precluded the generation of Western pressure in general, technocratic channels for such pressures were virtually redundant. As an arena where Western pressure or influence can be generated, technocratic linkages warrant further discussion, however. Western pressure or influence over Singapore's technocrats tended to be limited because Singapore came to represent technical-bureaucratic rationality par excellence, often perceived as an exemplar of corruption-free governance in the eyes of the West. The pragmatism of the leadership also allowed for judicious state intervention in the economy-which came to gain respect in technocratic circles of international organisations like the World Bank in the 1990s as the East Asian developmental state model began to gain currency (Birdsall et al. 1993). Moreover, the propensity of Singapore's government to exercise fiscal prudence made it attractive to economic conservatives amongst the technocratic and political elites of the West. The outpouring of praise from heads of state in the West following former Prime Minister Lee Kuan Yew's recent passing is telling of their admiration for the strongman rule that laid the social basis for that technical-bureaucratic rationality (Cram 2015).

It is important to note, however, that although Western influence was not forthcoming at the technocratic level, this dimension of linkage has not 
so far served to create domestic constituencies with a stake in adhering to democratic norms in part because the success of the "Singapore model" helped to instil a degree of pride in Singaporeans, reinforced by the admiration of foreign technocrats that have visited to learn about Singapore's "model" of development (Tan 2015). Of course, many of the students who went abroad to study at institutions of higher education in the UK and US were largely government sponsored from the late 1970s onward, and their future (well-paid) careers were predicated on the assumption of loyalty to the party-government (Wah Piow Tan, interview 18 December 2007). ${ }^{4}$ However, there is an ideational dimension that cannot be discounted. Singapore's economic success has allowed the "institutionalised ideology that champions the role of technocratic political elites," as Rodan and Jayasuriya (2012) have pointed out, to forge a strong identity amongst themselves and the wider middle classes employed by state apparatus or industries related to the state. The logic of technical-bureaucratic rationality continued to frame the reorientation strategy toward the knowledge economy in the 1990s, reinforcing this ideology (Leong 2011). As the West continues to ignore, for the most part, the authoritarian aspects of Singapore's state capitalism, technocratic linkages are unlikely to be a source of Western influence that creates constituencies with a state in adhering to democratic norms, or indeed, become an arena where external pressure that strengthens democratic forces in Singapore is generated.

Last in this discussion is that of informational linkages to the West, which potential to raise the cost of authoritarianism is twofold. Outward flows of information on authoritarian abuse from Singapore to the West can heighten its salience there and increase the probability of an international response. Inward flows of information from the West on the virtues of Western liberal values, ideas and institutions can create domestic constituencies with a stake in adhering to domestic norms by, for example, framing problems such as the lack of accountability as a symptom of authoritarian rule. Whilst telecommunications technologies in the 1970s and 1980s lent themselves more easily to censorship, such infrastructure has been well established for international commercial reasons. Control of Western-media penetration in Singapore was much tighter in the 1970s and 1980 s, and subject to more effective censorship from time to time before the advent of the internet. Since informational linkage to the West was unavoidable, however, the PAP leadership's strategy has been to circumscribe the content related to the authoritarian nature of Singapore's government as much as possible. The 1986 Newspaper and Printing Presses (Amendment) Act was thus introduced to provide the government the right to restrict the circulation of foreign publications deemed to engage in the 
domestic affairs of Singapore (Seow 1998). The numerous defamation suits filed against international news agencies and foreign journalists critical of its authoritarian rule in the compliant courtrooms of Singapore is also part of this strategy. Although this prong of the PAP's strategy really began with intensity during the late 1980 s and 90 s, it has carried on into the $2000 \mathrm{~s} .{ }^{5}$ Of course, this had the effect of advertising the authoritarian nature of the PAP government to the West, suggesting that the PAP leadership was most interested in mediating the effects of the inward flow of information in the age of Western liberal hegemony. It is in such an ideological context that the "Asian values" discourse promulgated by Prime Minister Lee Kuan Yew should also be understood as yet another prong of the PAP's strategy to mediate the impact of informational linkages with the West (Zakaria 1994). Indeed, the inevitability of such linkages necessitated an "Asian values" counter-discourse founded on the self-confidence of the pre-1997 "economic miracle."

Informational linkages have, indeed, heightened the salience in the West of authoritarian government abuse, not least because of the PAP leadership's strategy to shape the content of the information flowing into Singapore from the West. That this did not increase the likelihood of an international response and help to generate external pressure requires that we reference the intergovernmental and economic linkages that disincentivised Western governments from strong reactions to crackdowns on media freedom. Informational linkages are nevertheless considered to have had some limited impact in creating domestic constituencies with a stake in adhering to democratic norms. Between the late 1980s and early 1990s, whether and how Singapore should liberalise in response to the zeitgeist of democracy sweeping through various regions of the world, including East Asia, became a concern of the government, reflecting the perceived need to forestall the possibility of anything resembling a people power movement. It has not been possible to truncate informational linkages with the West for commercial reasons, nor to successfully circumscribe the inflow of information, such that Western liberal democratic ideas and values would not take some hold. This has, indeed, become much more difficult since the widespread use of the internet, but is associated, of course, with extensive social linkages to the West.

That neither technocratic, intergovernmental and economic linkages to the West have raised the cost of authoritarianism by generating and channelling external pressure or influence is evidenced, amongst other things, by the way in which Western-led international organisations have not hesitated to hold its meetings in Singapore. For example, in 2006, 
President Wolfowitz criticised the PAP government for banning protests during the World Bank meeting, yet a steady working relationship continued (New York Times 15 September 2006). Informational linkages have had some impact in raising the cost of authoritarianism by helping to make Singaporeans aware of how accountability and responsiveness can be at stake when such institutions are not strong, especially in recent years. ${ }^{6}$ This, however, is the extent of Western influence, as there has been no intent on the part of the West to take further action to undermine the stability and durability of a regime that has served Western interests so well. This agency-centred approach helps us to better perceive the enduring political and economic interests of the West at play with policies and actions of the PAP leadership to preclude and mediate the potential impact of these dimensions of linkage.

As such, we turn our attention now to social and civil society linkages. Our analysis so far implies that the grassroots nature of these forms of linkage may offer a greater potential in heightening the salience of authoritarian government abuse to the West, increase the probability of an international response and strengthening democratic forces in relation to autocrats. Other detailed empirical studies have shown that social and transnational civil society actors that make up such linkages have in other cases generated external pressures that have helped to effect democratisation in Taiwan and South Korea by framing authoritarian abuses as human rights violations (Ooi 2009; 2013). Indeed, the Helsinki Process (1973-1975) brought about an international normative shift where human rights became a legitimate international concern that could affect interstate relations. Transnational human rights organisations proliferated worldwide, empowered by this new normative environment to frame authoritarian abuse as morally reprehensible human rights violations that required international censure (Thomas 2001). Despite such a favourable normative environment, social and civil society actors that attempted to generate external democratising pressure by appealing to the moral conscience of the West nevertheless failed in Singapore. The approach taken in the following analysis foregrounds the politics of such forms of linkage by taking a similarly agency-centred approach. The rich empirical details in this section reveal social and transnational civil society linkages as arenas of political interaction-where grassroots actors work to generate external democratising pressures whilst the target government takes action to preclude and resist such pressures. This approach, as we shall see, better explains why such social and transnational civil society linkages failed to raise the cost of authoritarianism appreciably. By highlighting the role of autocratic agency in mediating the impact of such linkages, we further 
understand why the quantity of linkages matters less than the nature of these linkages.

\section{SOCIAL AND CIVIL SOCIETY LINKAGES TO THE WEST}

Social and transnational civil society linkages were extensive and diffuse in the case of Singapore precisely because its colonial history created a pattern of population flows with the West that spread these transnational networks thin. Political exiles and emigrants could be found in many Englishspeaking Western countries such as UK, Canada, US, Australia and New Zealand but the globalised outlook of Singapore society also helped to establish linkages to other Western European countries. Importantly, the diffuse pattern of social and transnational civil society linkages rendered them vulnerable to disruption at key historical moments by the PAP government. Further, actions taken to disrupt such linkages in the short run had the longer term impact of depoliticising the actors that make up such linkages, concomitant with efforts to do so with domestic civil society.

Indeed, the depoliticisation of social and transnational civil society linkages is not divorced from the PAP government's longstanding management of society (Lee 2005). This process is well recorded and analysed by others, who have shown that the general quiescence of the 1960s and 1970s could not be replicated in the 1980s and 1990s, however, and outright repression had to be replaced by co-optive methods that nevertheless subordinated "civic society" to the state agenda thereafter (Koh and Ooi 2004). What is often missed is the management of the relationships that are formed between societal groups that provide "alternative constructions of the 'truths' of societal situations" and solidarist associations or movements abroad, which had the potential to heighten the salience in the West of authoritarian government abuse, increase the probability of an international response, or strengthen the political opposition (Chua 2000). Where such groups express sympathies or openly support the PAP's political competitors, they are treated as potential rival centres of power and dealt with accordingly. For example, following the Helsinki Process, one of the more prominent Catholic activists in Singapore, Father Patrick Goh, attempted to set up a Human Rights Committee opposed to detention without trial and other arbitrary restrictions of freedom. This committee, established in 1977 as transnational human rights networks proliferated worldwide, consisted of the political opposition previously detained under the ISA. Because of the leftist leanings of those involved, this initiative was 
alleged to be a front organisation for a communist revival and quickly disbanded (Amnesty International 1978). From then on, only ecumenical organisations that avoided challenging the PAP government and its policies or supporting the political opposition were allowed to exist. The precedent that this episode of repression set, along with a decade of spectacular economic growth, led to a period of social quiescence.

By 1981, J. B. Jeyaretnam of the Workers' Party became the first opposition politician to be elected into Parliament since 1965. Importantly, a group of liberal minded lawyers, Christian social workers, student leaders and other members of the professional middle class critical of various aspects of government policy began to join or show sympathy to the opposition Workers' Party. By 1984, the growing electoral strength of the opposition became more apparent, as two opposition candidates were elected to Parliament and the PAP garnered only 62 percent of the vote in the general election of that year. By the mid-1980s, civic organisations that challenged state orthodoxy, such as the Association of Action and Research for Women (AWARE), also began to appear. Although the political opposition remained weak, by the late 1980s the possibility of political change presented itself in the form of the zeitgeist of democracy, which seemed to have swept across the globe. Importantly, a new generation of leaders in the ruling PAP was poised to take the reins at around the same time - and had hinted at the possibility of a new era of political liberalisation in keeping with these international trends. These international and domestic developments thus encouraged a nucleus of dissension to form, bringing together independent social activists and the political opposition. Two important breeding grounds for extra-parliamentary political opposition emerged in the 1980s - the Law Society and the Catholic Church. Many of their members were Western-educated, and maintained social, professional and organisational ties to the West, sometimes via parts of Asia which had more liberal political environments or had experienced people power movements. In other words, politicised social and transnational civil society linkages were forming.

It was thus in May 1987 that the PAP government dramatically revealed that they had smashed a transnational network of Christian ecumenical organisations and lawyers with links to international human rights organisations and certain student activists abroad. These were accused of being Marxists who planned to violently overthrow the government and establish a socialist order in Singapore. To date, scholars have failed to understand Operation Spectrum as an attack on transnational civil society and social linkages to the West - politicising over a period of time - that could have strengthened the political opposition by lending them 
international support (Barr 2008). Yet, the words of then-Home Affairs Minister Jayakumar betray this intent, "The Government could have decided let's wait, don't do anything. Wait for two, three years... But that means that the network would have proliferated (New York Times 21 June 1987).

Indeed, dissent from within the legal profession was particularly troublesome to the PAP government precisely because lawyers were conversant with the legal means of political repression and societal control, and had connections with international human rights organisations that were focused on the rule of law. One of the first signs of resistance to authoritarian rule came in 1986, when the Law Society publicly criticised amendments that were made to the Newspaper and Printing Presses Act to restrict the foreign press from circulating reports on political issues in Singapore - an attempt to manage informational linkages to the West. In January 1986, an independent-minded former Attorney General, Francis Seow, became president of the Law Society and under his tenure the Society demanded that the body be consulted on a a variety of judicial and legal appointments. At the LAWASIA Biennial Conference on 29 June 1987, for example, he appealed to "concerned and caring international organizations... to exert pressure on the Singapore government to put [the accused] on trial in a court of law or release them" (Seow 1994: 137). Such appeals did not fall on deaf ears-some 200 organisations worldwide protested the detention of the 22 individuals rounded up in Operation Spectrum, much to the chagrin of the PAP government and possibly a reason for which most of them were not long released despite the leeway for indefinite detention provided by the ISA (The Straits Times 27 June 1987).

Seow was a particular threat to authoritarian continuity in Singapore at this time of leadership transition. Forced to resign from the office of Law Society president, he joined the Workers' Party in August 1988 to contest the September general elections. Crowds gathered in significant numbers during Workers' Party campaign rallies and the PAP won by only a very narrow margin in Eunos Constituency. Interestingly, Seow was later arrested under the ISA for being a willing partner to "foreign interference" in Singapore's internal affairs in some unspecified plot to undermine the PAP government (New York Times 21 June 1987). Specifically, US diplomats, including Mason Hendrickson, were accused of meddling in Singapore politics by encouraging Seow to enter politics, while Seow was accused of receiving monies from the American government and seeking to secure the possibility of political asylum in the US should there be reprisals for challenging the PAP (Seow 1994: 121-45). These accusations highlight the importance placed by the PAP government on truncating transnational 
civil society and social linkages that could strengthen the political opposition.

This particular episode strained US-Singapore relations at the time (New York Times 12 May 1988). While transnational civil society and social linkages to the West had already helped to create the outpouring of international disapproval for the crackdown on Seow and the "Marxist conspirators," such accusations compelled US Secretary of State Schultz to discuss the case with Singapore officials, implying that private diplomatic pressure could have been applied at this time (New York Times 21 June 1987). There were no further repercussions down the road as economic and intergovernmental cooperation continued, however. Amnesty International nevertheless named Seow (and later, all 22 detainees of Operation Spectrum) a "prisoner of conscience" to highlight his plight and upon release, Human Rights Watch invited him to the US, where he has remained since November 1988 to publish three books to continue raising the profile of the PAP government's brand of authoritarian rule in the West (Associated Press 22 August 1988; Seow 1994: 256).

Connections that local lawyers had with international human rights organisations such as the International Commission of Jurists (ICJ) was also troublesome because the ICJ kept a close eye on the use of law for repressive purposes in Singapore, and had in the past even helped to procure external counsel in defamation cases, periodically filed by the PAP leadership against the parliamentary opposition to bankrupt and disqualify them from their seat. The ICJ sent a fact-finding mission to Singapore in July 1987, interviewing Seow, opposition parliamentarian J. B. Jeyaretnam, and the family and friends of those "Marxist conspirators," presenting their findings in a publicly circulated report that discredited the PAP government's claims of a Marxist conspiracy (New York Times 21 June 1987). The ICJ also invited Seow to a conference in Bangkok in December 1987 and June 1988 to further raise international awareness of political repression in Singapore. Other organisations such as the Lawyers Committee for Human Rights (later, Human Rights First) and the International Human Rights Law Group also served as expert witnesses during US Congressional Hearings over the human rights situation in Singapore, which took place as a result of urgings by human rights activists during this times. ${ }^{7}$ In short, linkage to these international human rights organisations not only heightened the salience in the West of authoritarian government abuse, it strengthened a nascent opposition movement.

Indeed, efforts to raise the international profile of Operation Spectrum did in fact help to generate some external pressure on the PAP government - the US Congress and even the European Parliament called for 
the immediate release of the ISA detainees, or an open trial (New York Times 21 June 1987). Members of the New Zealand Parliament expressed public concern in April 1988, as did members of the Japanese Diet, when rearrests were made of those who had been previously released in 1987 (Rerceretnam 2006). These concerns were raised precisely because of the outcry stirred up by human rights activists, Christian churches and ecumenical organisations abroad, along with student bodies that objected to the use of the ISA to crack down on seemingly innocent individuals. However, Western countries did not use other heavy handed approaches such as economic sanctions to exert pressure on the PAP government, consistent with the earlier claim that Western economic and political interests vested in the Singapore leadership did, in fact, disincentivise an outright campaign to delegitimise the PAP government. Activists from such international human rights organisations would soon find themselves closely observed or obstructed from entering Singapore. The PAP government also disrupted these linkages by making an example of those who tried to establish contact with any kind of foreigners that could help to generate external pressure at this time-lawyer Patrick Seong, for example, was labelled a "propagandist" and later detained simply for providing information to the foreign press during the 1987 arrests (The Online Citizen 26 May 2009). Another way the PAP government disrupted those linkages was by framing the international support given to the ISA detainees as "foreign interference" in the domestic affairs of Singapore, making it clear to social activists, the political opposition and all potential dissidents in Singapore that any foreign support they gained would be considered a threat to national security and treated accordingly (Seow 1994: 107). Such moves had the dual effect of immediately causing independently-constituted civil society groups to dissociate themselves in the short term from their Western counterparts, while depoliticising them in the longer run.

Another important source of potential opposition during the $1980 \mathrm{~s}$ came from within Christian ecumenical organisations. Ten of the original 16 detainees of Operation Spectrum had worked for Catholic ecumenical organisations concerned with issues of social justice and human rights, or were members of Catholic student organisations with connections to other such organisations abroad (Barr 2008: 228-46). Indeed, the "Marxist" aspect of the alleged conspiracy referenced in part the history of progressive social activism of the targeted Christian groups in Singapore and in part "liberation theology," which had more recently played a role in the democratic breakthrough in South Korea and the Philippines (Straits Times 20 August 1987; Richburg 1987). This growing Christian movement was, in 
fact, increasingly multidenominational and thus potentially broad-based. Even more worrying for the PAP government were their linkages to similar organisations across Western societies, which support could strengthen the political opposition. The Christian Conference of Asia (CCA), which was shut down because of its support of the "Marxist conspirators," was just such an example of a regional, multidenominational ecumenical organisation linked to a larger international organisation, the World Council of Churches (WCC).

Indeed, numerous church and ecumenical leaders in Australia and Japan, South Korea and other places in Asia such as the Philippines, protested Operation Spectrum and advocated for the release of those detained without prospect of trial (O'Grady 1990: 13-22). The CCA further mounted a campaign against the arrests of the "Marxist conspirators" from its subsidiary bodies in Hong Kong and some of its member Councils of Churches (Rerceretnam 2006: 20). Further, the Asian Human Rights Commission, linked to the CCA, sent a fact-finding mission in July 1987 along with the ICJ, which concluded in its report that those detained should be "defended and applauded" (Asian Human Rights Commission 1987: 27). The CCA also financially supported the ad hoc Emergency Committee for Human Rights in Singapore (ECHRS), based in Christchurch, New Zealand, which produced fortnightly newsletters between May 1987 and October 1988 to publicise and inform on Operation Spectrum. The Ecumenical News Service of the World Council of Churches carried news of the crackdowns abroad while in May 1988, recommendations were made at the Churches Commission on International Affairs - an advisory body of the WCC - that the WCC boycott Singapore Airlines when rearrests were made the month before (O'Grady 1990: 13-22). The WCC did just that. In the midst of such external pressure, the PAP leadership was determined to crush the progressive Catholic leadership which had reaffirmed the need for the Church to engage in issues of social justice, support the detainees and was receptive of international support. Four such Catholic priests were pressured into resigning after a meeting with Prime Minister Lee was held with the Catholic leadership. The Archbishop was later compelled to issue ecclesiastical sanctions on them and to shut down the Catholic Center. These priests left separately for Europe, Canada and Australia, effectively disrupting this aspect of transnational civil society linkages to the West at the time.

Social linkages to the West, in the particular form of Singaporean students and political exiles living abroad, were also targeted by the PAP government because of their potential to generate and channel external pressure or influence on the new generation of PAP leaders. Tan Wah Piow, 
named the sinister mastermind of the "Marxist Conspiracy," was at the time a law student at Oxford University after having been forced to leave the country for anti-Vietnam war student activism in the 1970s. Tan led the Federation of United Kingdom and Eire Malaysian and Singapore Students' Organizations (FUEMSSO) and was viewed as a threat precisely because his position gave him the potential to politicise and influence returning students. The Hong Kong-based Asian Students Association (ASA), which maintained connections to FUEMSSO, was also held in suspicion for politicising returning students. ${ }^{8}$ Further, a connection between the Catholic progressive movement, Tan, and local students was apparently appearing. Thus, many of the ISA detainees had been members of the Polytechnic Students' Union involved with Catholic ecumenical organisations or members of the Catholic Association of Polytechnic Students. Operation Spectrum disrupted these social linkages and the potential they had to nurture and support the political opposition in Singapore. Indeed, Tan and other former student activists based in Hong Kong and Europe formed the European Committee on Human Rights in Malaysia and Singapore (KEHMA-S) to protest Operation Spectrum, vindicating PAP suspicions of these transnational networks' ability to generate external pressure and bring it to bear on them. ${ }^{9}$

However, what the PAP government may not have grasped was that the students most active in generating external pressure would be based in Australia, since fewer of them were dependent upon government scholarships. An important student organisation that actively objected to Operation Spectrum was collectively known as the Network of Overseas Student Collectives in Australia (NOSCA). Interestingly, NOSCA maintained extensive links with regional and international nongovernmental organisations organised around causes that spanned across a wide range of issue areas, making them particularly well-connected. NOSCA organised the Malaysia Singapore Human Rights Commission, held public meetings about the "Marxist Conspiracy," published literature, ran media campaigns and lobbied other student organisations and Australian politicians to support the detainees of Operation Spectrum over 1987-1988. These efforts prompted the Australian government to raise the issue at a regional foreign ministers' meeting (US State Department 1982: 798). In 1989, NOSCA even staged a public protest in Sydney to embarrass visiting Brigadier-General Lee Hsien Loong. It is not surprising that the PAP government publicly acknowledged that the greatest degree of external pressure came from nongovernmental organisations based in Australia (The Straits Times 27 June 1987). 
The 1987 arrests served as a focal point for the above transnational civil society and social actors to converge their efforts on heightening the salience in the West of authoritarian government abuse and to increase the probability of an international response. This was an important moment in Singapore's political history because the impending leadership transition could have sensitised the leadership to external pressure. Owing to actions taken to truncate these linkages, only limited pressure could be generated, however. Efforts to depoliticise civil society and other social actors and their linkages to the West had a lasting impact into the post-Cold War period, explaining why these linkages have not since generated any appreciable external pressure that could have raised the cost of authoritarianism for the PAP government. Although inherent structural weaknesses rendered these forms of linkage to the West susceptible, the deliberate policy of the PAP to depoliticise these linkages is a significant factor for which they have not had the kind of impact suggested by the current literature.

Indeed, subsequent to Operation Spectrum, the PAP government began vigorously shaping the discourse on civil society by redefining it as "civic society" (Lee 2005). Brigadier General George Yeo's 1991 promulgation of the term "civic society" stressed civic responsibilities rather than the rights of citizenship, whilst the subsequent policy of marginalising a handful of groups that refused to be so co-opted effectively depoliticised civil society and subordinated it to state preferences. Under Prime Minister Lee Hsien Loong, the term "civil society" was reintroduced with little appreciable difference in substance to the earlier understanding. Importantly, the "Marxist Conspiracy" debacle etched in public memory the dangers of politicised linkages with the West, and the many international nongovernmental organisations in Singapore today are also mindful of the parameters of operation. An example of one organisation with social and civil society linkages to the West may suffice to explain the consistency of the PAP's policies - that of the Singaporeans for Democracy (SFD), established in 2010. Led by an internationally-based Singaporean academic, the SFD worked closely with the United Nations Human Rights Council on the Universal Periodic Review process and stressed the maintenance of relationships with similar international nongovernmental organisations. It was dissolved in 2012 after protracted legislative obstacles to its registration presented by the PAP government. 


\section{CONCLUSION}

S. R. Joey Long once observed of Singapore that, "the notion of an island entity - geographically situated at one of the most important and strategic economic crossroads in the world - that is impervious to external influences and developments is conceptually limited and historically unrealistic" (2011: 216). Regime change in Singapore cannot be understood without locating it at the international-domestic political interface. The theoretical framework provided by Levitsky and Way (2010) does just that. Unfortunately, the structural approach they have taken in the conceptualisation of linkages to the West has presented obstacles to a better understanding of why linkage to the West sometimes fails to raise the cost of authoritarianism. The analysis provided here helps us to rethink linkages to the West as inherently political by foregrounding the agency and process through which external pressure and influence are generated, minimised or precluded by state and nonstate actors that are an inherent part of these linkages. By reconceptualising linkages as sites of political interaction, we are better able to see more specifically how autocratic agency can mediate the impact of intergovernmental, economic, technocratic, informational, social and transnational civil society linkages to the West. Indeed, a closer examination of each dimension of Singapore's linkage to the West has revealed that not all dimensions of linkage have served to generate or channel external pressure or influence on the PAP government, depending on what policies and actions it has pursued. This observation suggests that a structural approach that treats linkage as mere channels of external democratising pressure or influence fails to give due attention to the politics of each dimension of linkage to the West. The agency-centred approach is arguably much truer to the purpose of Levitsky and Way's theoretical framework, which is meant to capture the international-domestic political interface of regime change (2010). The extent to which the claims made here are generalisable remains to be seen through other detailed studies of cases where linkages to the West have not led to democratisation. While this is beyond the scope of the present undertaking, rethinking linkage to the West in the way suggested here certainly opens up the research agenda in the field of regime change studies in a new direction not suggested by the current literature. 


\section{NOTES}

* Su-Mei Ooi is Assistant Professor at Butler University's Department of Political Science. Her research interests span comparative democratisation, human rights, transnational activism and US-China relations. Her regional specialisation is in the Pacific Asian region. Recent publications include "The Transnational Protection Regime and Taiwan's Democratization" and "The Transnational Protection Regime and Democratic Breakthrough in Taiwan and South Korea." She also contributes feature articles to The Diplomat and other news media outlets.

1 The increasingly popular opposition Workers Party, whose appeal to the electorate for a "First World Parliament" that could hold the PAP government accountable during the 2011 General Elections, further underlines the awareness Singaporeans have of Western liberal democratic institutions and their value, drawing comparisons with their own political institutions.

2 According to the World Bank, foreign direct investment ranged around 6-14 percent of Singapore's GDP between 1980 and 1991 a comparatively high level amongst developing countries. World Bank, http://data.worldbank.org/country/singapore (accessed 10 September 2015).

3 US State Department Country Reports on Human Rights has consistently registered concerns over the use of the Internal Security Act in Singapore since 1975, along with increasing restrictions on press freedom and civil society and long-held political detainees. Human Rights organisations have also raised issues with long-held political detainees, and importantly reported on the subtle legalistic means through which political dissent has been muzzled in widely available reports. For example, when Amnesty International started reporting on Singapore in 1975, it raised concerns about how the Banishment Act was used to hold some detainees indefinitely without trial without having to resort to the Internal Security Act.

4 See also Singapore and Malaysian British Association (SiMBA) Newsletter, 5 July 1994, 3. SiMBA was a UK-based student organisation.

5 In 2002, for example, Bloomberg paid large damages to the political leadership and issued a high profile public apology for suggesting the practice of nepotism in the top leadership ranks. In 2006, the Far East Economic Review was forced to pay US\$290,000 to the Lee family in an out-of-court settlement for an allegedly defamatory article.

6 The increasingly popular opposition Workers Party, whose appeal to the electorate for a "First World Parliament" that could hold the PAP government accountable during the 2011 General Elections, further underlines the awareness Singaporeans have of Western liberal democratic institutions and their value, drawing comparisons with their own political institutions.

7 United States Congress House of Representatives Committee on Foreign Affairs Subcommittee on Human Rights and International Organizations, Recent Developments in Malaysia and Singapore 1988: Hearings Before the Subcommittee on Human Rights and International Organizations of the Committee on Foreign Affairs, House of Representatives, One Hundredth Congress, Second Session, 7 July and 22 September 1988 (Washington, DC: Library of Congress, 1988).

8 There is evidence that ASA and FUEMSSO had begun to make contact since 1981 signalling a coalescing student movement abroad in the aftermath of attempts to 
suppress the student movement in Singapore in the mid-1970s. See Fijar No. 14 October 1981, 14. Fijar was the monthly publication of FUEMMSO.

9 See 2nd Press Statement, European Committee for Human Rights in Malaysia and Singapore, Brussels, 10 March 1989.

\section{BIBLIOGRAPHY}

Amnesty International. 1978. Amnesty International (AI) annual report 1978, index no. POL 10/001/1978 London, AI International Secretariat.

Amnesty International charges torture of Singapore detainees. 1988. Associated Press, 22 August.

Asian exemplar moves toward authoritarianism. 1988. New York Times, 12 May.

Asian Human Rights Commission, International Commission of Jurists and International Federation of Human Rights. 1987. Report of the international mission of jurists to Singapore to investigate the arrest and detention of 22 persons in May and June 1987, Geneva, International Commission of Jurists.

Barr, M. D. 2008. Singapore's catholic social activists: Alleged Marxist conspirators. In Paths not taken: Political pluralism in post-war Singapore, eds. Barr, M. D. and Trocki, C.A., 228-246. Singapore: National University of Singapore Press. . 2010. Marxists in Singapore? Lee Kuan Yew's campaign against Catholic social justice activists in the 1980s. Critical Asian Studies 42: 335-362, DOI:10.1080/14672715.2010.507389

Barr, M. D. and Skribis, Z. 2008. Constructing Singapore: Elitism, ethnicity and the nation-building project. Copenhagen: NIAS Press.

Birdsall, N. et. al. 1993. The East Asian miracle: Economic growth and public policy. New York: Oxford University Press.

Brownlee, J. 2007. Authoritarianism in an age of authoritarianism. Cambridge: Cambridge University Press.

Chua, B. H. 2000. The relative autonomies of the state and civil society. In Statesociety relations, ed. Koh, G. and Ooi, G. L. Oxford and New York: Oxford University Press.

Collier, R. B. 1999. Paths toward democracy: The working class and elites in Western Europe and South America. Cambridge: Cambridge University Press.

Cram, C. 2015. The UK can learn a lot from Lee Kuan Yew and Singapore. The Guardian, 4 April.

Finegold, D., Wong, P.-K. and Cheah, T.-C. 2004. Adapting a foreign direct investment strategy to the knowledge economy: The case of Singapore's emerging biotechnology cluster. European Planning Studies 12: 921-941. 
Singapore is holding 12 in 'Marxist Conspiracy.' 1987. The New York Times, 21 June.

Four US littoral combat ships to operate out of Singapore by 2018. 2015. The Diplomat, 19 February.

Geddes, B. 1999. What do we know about democratisation after twenty years? Annual Review of Political Science 2: 115-144, DOI: 10.1146/annurev. polisci.2.1.115.

Gill, I., Huang Y. and Kharas, H. J. 2006. East Asian visions: Perspectives on economic development. Washington: World Bank.

Gillis, K. E. 2005. Singapore civil society and British power. Singapore: Talisman Publishing.

Goh, K. S. 1999. The economics of modernization. Singapore: Federal Publications.

Guan, A. C. 2009. Singapore and the Vietnam War. Journal of Southeast Asian Studies. 40: 353-384, DOI:10.1017/S0022463409000186.

Haggard, S. and Kaufman, R. 1995. The political economy of democratic transitions. Princeton: Princeton University Press.

How I used the church. 1987. The Straits Times, 27 June.

Howard, M. M. and Roessler, P.G. 2006. Liberalizing electoral outcomes in competitive authoritarian regimes. American Journal of Political Science 50: 365-381, DOI:10.1111/j.1540-5907.2006.00189.x.

Huff, W. G. 1994. The economic growth of Singapore: Trade and development in the twentieth century. Cambridge and New York: Cambridge University Press.

Huntington, S. P. 1991. The third wave: Democratisation in the late twentieth century. Norman: University of Oklahoma Press.

International Mission of Jurists. 1987. Report of the international mission of jurists to Singapore 5-9 July 1987 to investigate the arrest and detention of 22 persons on May and June 1987, Geneva.

Johnson, C. 1982. MITI and the Japanese miracle: The growth of industrial policy, 1925-1975. Stanford, CA: Stanford University Press.

Khong, C. O. 1995. Singapore: Political legitimacy through managing conformity. In Political legitimacy in Southeast Asia: The quest for moral authority, ed. Alagappa, M, 108-135. Stanford: Stanford University Press.

Koh, G. and Ooi, G. L. 2004. Relationship between state and civil society in Singapore: Clarifying the concepts, assessing the ground. In Civil society in Southeast Asia, ed. Lee, H. G. Singapore: Institute of Southeast Asian Studies.

Lee, T. 2005. Gestural politics: Civil society in "new" Singapore. Sojourn: Journal of Social Issues in Southeast Asia 20: 132-154.

Leifer, M. 1986. The Vietnam War and the response of Southeast Asian countries. Paper presented at 30th Anniversary International Conference, Japan Association of International Relations, 4-8 September. 
Leong Y. 2011. A brief history of the hub: Navigating between 'global' and 'asian.' In Singapore's knowledge economy discourse, eds. Heng, D. T. S. and Aljunied, S. M. K. Amsterdam: Amsterdam University Press.

Levitsky, S. R. and Way, L. A. 2005. International linkage and democratisation. Journal of Democracy 16: 20-34, DOI:10.1353/jod.2005.0048. . 2006. Linkage versus leverage: Rethinking the international dimension of regime change. Comparative Politics 38: 379-400, DOI:10.2307/20434008. . 2007. Linkage, leverage and the post-communist divide. East European Politics and Societies 27: 48-66, DOI:10.1177/0888325406297134. . 2010. Competitive authoritarianism: The origins and evolution of hybrid regimes after the Cold War. New York: Cambridge University Press. . 2012. Beyond patronage: Violent struggle, ruling party cohesion, and authoritarian durability. Perspectives on Politics 10: 869-889, DOI: $10.1017 / \mathrm{S} 1537592712002861$.

Lipset, S. M. 1959. Some social requisites of democracy: Economic development and political legitimacy. American Political Science Review 53: 69-105.

Long J. S. R. 2011. Bringing the international and transnational back in: Singapore, decolonisation, and the Cold War, In Singapore in global history, eds. Heng, D. and Aljunied, S. M. K., 215-234. Amsterdam: Amsterdam University Press.

Low, L. 1998. Political economy in a city-state: Government-made Singapore. Singapore: Oxford University Press.

Marxism's chilling new theology. 1987. Straits Times, 20 August.

Moore, B. 1966. Social origins of dictatorship and democracy: Lord and peasant in the making of the modern world. Boston: Beacon Press.

O'Grady, R. 1990. Banished: The expulsion of the Christian Conference of Asia from Singapore and its implications. Hong Kong: CCA International Affairs Committee.

Ooi, S-M. 2009. The transnational protection regime and Taiwan's democratisation. Journal of East Asian Studies 9: 57-85. . 2013. The transnational protection regime and democratic breakthrough in Taiwan and South Korea. Democratisation 2: 311-334, DOI:10.1080/ 13510347.2012.729045.

Operation Spectrum was political rape. 2009. The Online Citizen, 26 May. http:// www.theonlinecitizen.com/2009/05/operation-spectrum-was-political-rape/ (accessed 29 October 2015)

Ortmann, S. 2011. Singapore: Authoritarian but newly competitive. Journal of Democracy 22: 153-164, DOI:10.1353/jod.2011.0066.

Parig, D. 1984. Churches in contestation: Asian Christian social protest. New York: Orbis Books.

Pereira, A. A. 2008. Wither the developmental state? Explaining Singapore's continued developmentalism. Third World Quarterly 29: 1189-1203. 
Pridham, G., Herring, E. and Sanford, G. 1994. Building democracy? The international dimension of democratisation in Eastern Europe. New York: St. Martin's Press.

Rahim, L. S. 2009. Singapore in the Malay world: Building and breaching regional bridges. London: Routledge.

Rerceretnam, M. 2006. The 1987 ISA arrests and international civil society: Responses to political repression in Singapore. The Copenhagen Journal of Asian Studies 23: 8-27.

Richburg, K. B. 1987. Singapore fears surge in communal tensions; Race, religion issues simmer below surface. The Washington Post, 16 September.

Rodan, G. 1989. The political economy of Singapore's industrialization: National state and international capital. Basingstoke: Macmillan. . 2004. Transparency and authoritarian rule in Southeast Asia: Singapore and Malaysia. London: Routledge.

. 2006. Singapore: Globalisation, the state and politics. In The political economy of Southeast Asia: Markets, power and contestation, eds. Rodan, G., Hewison, K. and Robison, R., 137-169. Melbourne: Oxford University Press.

Rodan, G. and Hewison, K. 2001. The political economy of South-East Asia: Conflict, crises, and change. Melbourne: Oxford University Press.

Rodan, G. and Jayasuriya, K. 2012. Hybrid regimes: A social foundations approach. In Routledge Handbook of Democratisation, ed. Haynes, J., 175-189. London/New York: Routledge.

Rueschemeyer, D., Stevens, H. E. and Stephens, J. D. 1992. Capitalist development and democracy. Chicago: University of Chicago Press.

Seow, F. T. 1994. To catch a tartar: A dissident in Lee Kuan Yew's prison. New Haven: Yale Center for International and Area Studies. . 1998. The media enthralled: Singapore revisited. Boulder, CO: Lynne Rienner Publishers.

Singapore braces to play host to IMF and the World Bank. 2006. New York Times, 15 September.

Sixteen are arrested for Marxist conspiracy. 1987. The Straits Times, 29 May.

Slater, D. 2010. Ordering power: Contentious politics and authoritarian Leviathans in Southeast Asia. New York: Cambridge University Press. . 2012. Strong-state democratisation in Malaysia and Singapore. Journal of Democracy 23: 19-33, DOI:10.1353/jod.2012.0021.

Smith, B. B. 2005. Life of the party: The origins of regime breakdown and persistence under single-party rule. World Politics 57: 421-451.

Tan, C. L. L. 2015. Pride and prejudice in modern Singapore. Foreign Policy, 24 March. http://foreignpolicy.com/2015/03/24/growing-up-in-lee-kuan-yewssingapore/ (accessed 26 March 2015)

Tan, E. S. 2004. Does class matter? Social stratification and orientations in Singapore. Singapore: World Scientific. 
Thomas, D. C. 2001. The Helsinki Effect: International norms, human rights, and the demise of communism. Princeton, NJ: Princeton University Press.

Thompson, E. C. 2006. Singaporean exceptionalism and its implications for ASEAN regionalism. Contemporary Southeast Asia 28: 183-206.

Trocki, C. A. 2006. Singapore: Wealth, power and the culture of control. London: Routledge.

US State Department. 1982. Country reports on human rights practices for 1982. Washington, DC: US Government Printing Office.

Whitehead, L. 2001. The international dimensions of democratisation: Europe and the Americas. Oxford: Oxford University Press.

Why different reactions to two sets of ISA arrests? 1987. The Straits Times, 27 June.

Woo-Cumings, M. 1999. The developmental state. Ithaca, NY: Cornell University Press.

Zakaria, F. 1994. A conversation with Lee Kuan Yew. Foreign Affairs 73:109126. 